\title{
MORPHOLOGICAL AND GENETIC RELATIONSHIPS OF MYOSOTIS LAXA SSP. BALTICA AND SSP. CAESPITOSA, AND TYPIFICATION OF M. LAXA SSP. BALTICA
}

\author{
Silvia Pihu ${ }^{1}$, MAARJA ÖPIK ${ }^{1,2}$, ENE KoOK ${ }^{1}$, Ülle ReIER ${ }^{1}$ \\ ${ }^{1}$ University of Tartu, Institute of Ecology and Earth Sciences \\ Lai 40, Tartu 51005, Estonia \\ e-mail: silvia.pihu@ut.ee \\ ${ }^{2}$ Scottish Crop Research Institute \\ Invergowrie, Dundee, DD2 5DA, UK
}

(Received: October 5, 2007. Accepted: April 16, 2008)

\begin{abstract}
Intraspecific taxonomy of Myosotis laxa has been unclear for a long time. M. laxa ssp. baltica has been treated as a microendemic taxon of the Baltic Sea region, which has evolved in the Åland Islands and has spread northwards; the spread to southeast has been declared doubtful. Morphologically intermediate individuals between $M$. l. ssp. caespitosa and M. l. ssp. baltica exist; these have sometimes been classified as M. l. ssp. laxa. The aim of this paper is to clarify phylogenetic relationships between subspecies of M. laxa s.l. Here, M. laxa ssp. baltica is lectotypified. We proved that typical M. l. ssp. baltica does occur in the south-eastern Baltic region, namely in Estonia, using herbarium and freshly collected material. A group of plants were identified as typical M. $l$. ssp. baltica, but many specimens showed intermediate characters between M. laxa ssp. baltica and ssp. caespitosa. The two subspecies could be clearly differentiated neither by morphological characteristics nor by ITS sequences. $M$. laxa s. l. appeared to be monophyletic according to the ITS phylogeny. We propose that Myosotis laxa ssp. balti$c a$ is a coastal ecotype of Myosotis laxa, which has adapted to the fluctuating conditions of coastal habitats. Genetically, it has not yet evolved into a separate species and therefore it would be reasonable to assign it a rank of variety. However, further investigation including wider taxon and geographical sampling is needed to finally clarify the position of all subspecies.
\end{abstract}

KEY WORDS: Baltic Sea region, phylogeny, rDNA ITS, microendemism, taxonomy.

\section{INTRODUCTION}

\section{Genus Myosotis}

The genus Myosotis (family Boraginaceae) contains about 100 species and is spread in temperate zones of northern and southern hemisphere. Molecular data support the hypothesis that the genus originates from the northern hemisphere (Judd and al. 2002; Winkworth and al. 2002). European species of the genus have been studied systematically using morphological and caryological characters (Schuster 1967; Grau and Schwab 1982; Przyvara 1986/1987; Apelgren 1990a, b, 1991). Still, some problematic taxa remain in the genus, for example, the M. laxa complex.

\section{The M. laxa Lehm. complex}

The complex contains three subspecies: M. laxa ssp. laxa, M. laxa ssp. caespitosa (Schultz) Hyl. ex Nordh., and M. laxa ssp. baltica (Sam.) Hyl. ex Nordh. M. laxa was described by Lehmann in 1818 , being the oldest name in this complex and is therefore used as the species name. It was described as an annual with weak branching and spreading stems, sparse inflorescences, small flowers, and calyces as well as pedicels much elongating after flowering (Lehmann 1818). Lehmann did not designate a type specimen, he only said that he has seen a dried specimen from NorthAmerica (Lehmann 1818), the present location of which is not known.

From Europe, M. caespitosa was described a year later by Schultz (1819). It differs from M. laxa by a more erect growth habit, lesser branching, denser inflorescences, shorter calyces and pedicels (which do not elongate considerably after flowering). The type material of $M$. caespitosa is indicated in type description as "ad pagum Ballin hinter dem Hofgarten, et prope Neobrandenb. am kleinen Jhlpol." (Schultz 1819), but has not been found subsequently (Schuster 1967) and it has not been possible to detect its present location in herbaria, either. Probably the same taxon was already mentioned by Lehmann (1818) as M. lin- 
gulata, a taxon with no description (nomen nudum). M. $l$. ssp. caespitosa is considered to be distributed in the entire northern Eurasia.

Lindberg (1915) first noticed a special coastal taxon of Myosotis in Åland and he identified it as M. laxa Lehm. Later, Samuelsson (1926) described probably the same taxon as a new species, $M$. baltica Sam. His species description was rather short, in Swedish and largely resembling that of M. laxa by Lehmann (1818); at the same time Samuelsson declared that this $M$. baltica is neither $M$. laxa sensu Lehmann nor sensu Lindberg (Samuelsson 1926). Samuelsson did not typify the name. Later, Lindberg (1934) stressed that M. baltica Sam. is the same taxon he had earlier mentioned as a coastal $M$. laxa and it corresponds to the Lehmann's description of M. laxa and should be treated under latter name (Lindberg 1934). Specimens from Exsiccatae Fennicae! and their photos (Lindberg 1915) confirm this. However, Lindberg (1934) admits that $M$. baltica differs from the American taxon generally regarded as M. laxa Lehm. (Britton and Brown 1898), and may therefore be treated as a separate species.

There has also been some confusion in the citation. $M$. baltica Sam. ex Lindm. (Schuster 1967) is wrong - M. baltica Sam. in Lindm. is correct, as the description was published in Lindman's flora (Samuelsson 1926), but with Samuelsson's name clearly indicated. However, the "in"phrase is mostly omitted nowadays. M. baltica Sam. ex H. Lindb. (The International Plant Names Index 2004. http://www.ipni.org, accessed 19.11.2007). is also not correct, as the publication of the species name by Samuelsson (1926) was completely valid considering that it was published before 1935. The clarification by Lindberg (1934) that this is the same species recognised by him as M. laxa does not change this. Thus the simplest form $M$. baltica Sam. is the best.

Currently prevalent understanding that caespitosa and baltica are subspecies of $M$. laxa was published in Norsk Flora (Nordhagen 1940). M. laxa ssp. laxa is a third, North American subspecies, as mostly interpreted. Apelgren (1991b) found that all three taxa are mutually continuous and lowered their taxonomic range to that of variety. She considered that M. l. ssp. laxa is amphiatlantic and all three subspecies or varieties also occur in Europe (Apelgren 1991b). The same view is now accepted in Sweden (Krok and Almquist 2004). However, some authors consider $M$. laxa ssp. laxa to include M. l. ssp. baltica (Hegi 1927; Schuster 1967; Lid and Lid 1994). This view is supported by finding baltica- or laxa-like plants in Kamchatka (Schuster 1967) and Japan (Saiki and Osegawa 1972).

Contrarily, some authors still consider the members of this complex as separate species (Nikiforova 2001; Cepurfte 2003). Earlier, the taxa have also been treated as subspecies of M. scorpioides L. (syn. M. palustris (L.) Nath.): M. s. ssp. laxa (Lehm.) Hegi and M. s. ssp. caespitosa (C. Schultz) Herm. (Hegi 1927).

\section{M. laxa ssp. baltica}

The taxon is restricted to the Baltic Sea region with rare findings from western Sweden and Norway (Hultén and Fries 1986). It is considered to be neoendemic and to originate from the Åland Islands in the Baltic Sea (Jonsell 1988; Apelgren 1991). According to Jonsell (1988), M. laxa ssp. baltica belongs to a group of coastal microendemics. This author considers Baltic microendemics as morphologically distinct taxa with restricted range in Scandinavia and other northern countries. Though the postglacial period in Scandinavia and Baltic countries is considered to be too short for speciation to take place (Ingelög et al. 1993), environmental conditions of the coastal zone of the Baltic Sea, namely land lifting, seasonal changes of water level and salinity as well as erosion, may accelerate the differentiation of populations (Jonsell 1988). The characteristic coastal microendemics are annual, early flowering, with shorter life cycle and autogamous, as opposed to the sister taxa occurring in the same region (Jonsell 1988).

M. laxa ssp. baltica is most common in south-western Finland and Åland (Ulvinen 1998) with decreasing occurrence northwards (Palmgren 1961; Apelgren 1990a). Åland has been proposed as a putative taxon formation centre (Palmgren 1961; Apelgren 1990a). It has been hypothesised that M. laxa ssp. baltica spread from Åland to the north of the Baltic Sea by prevailing streams (Apelgren 1990b). Palmgren (1927) claimed that this species does not occur in Estonia, referring to Kupffer (1925). However, M. balti$c a$ was described in 1926 (Samuelson 1926) and Kupffer could not have been aware of it at the time. Still, Apelgren (1990b, 1991) also expresses doubts about the presence of typical $M$. baltica in Estonia. She does not refer to the material from the Estonian herbaria and has seen only some, probably not typical specimens collected from Estonia, not indicating the source of this material. She also relies on the theory that the taxon has developed in Alland and on the fact that there are no streams from there to south (the prevailing streams in the Baltic Sea go counter-clockwise; Alhonen 1966). On the contrary, M. laxa ssp. baltica is stated to occur in Estonia in the atlas of European Flora (Hultén and Fries 1986) and in several keys and floras (Viljasoo 1969; Lazdauskaite et al. 1996; Reier 1999; Cepurfte 2003). The taxon has been found from western Estonia and the islands (Kukk and Kull 2005; Fig 1), though it is relatively rare, occurring more abundantly on small islets (Viljasoo 1969; Vissak 1991; Ploompuu 1995; Rebassoo 1960, 1997).

M. laxa ssp. baltica grows on the seashore, where moisture and salinity fluctuate considerably during the vegetation period, and there is a danger of erosion or of getting buried (Ericson and Wallentinus 1979). Characteristic features of the taxon are actually adaptations to such changing conditions. Larger seeds/fruits enable faster sprouting and growth as well as promoting growth in unfavourable conditions, for example, in the dark under the sand or seaweed layer (Harper 1977; Weller 1985; Baskin and Baskin 1998). As seed size is one of the least plastic characters, this should be regarded as an adaptation (Harper 1977). M. laxa ssp. baltica flowers earlier than other subspecies, during the period when the water level is at its lowest (Ericson and Wallentinus 1979; Apelgren 1991). As the flowering starts soon after sprouting, the flowers are formed on the lower part of the stem; this is why there are leaves in the inflorescence. In cultivation, M. laxa ssp. baltica also started flowering two weeks earlier than M. laxa ssp. caespitosa (Apelgren 1986, 1991). Most of the diagnostic features persisted in cultivation, thus they should be genetically determined (Apelgren 1990b, 1991). 


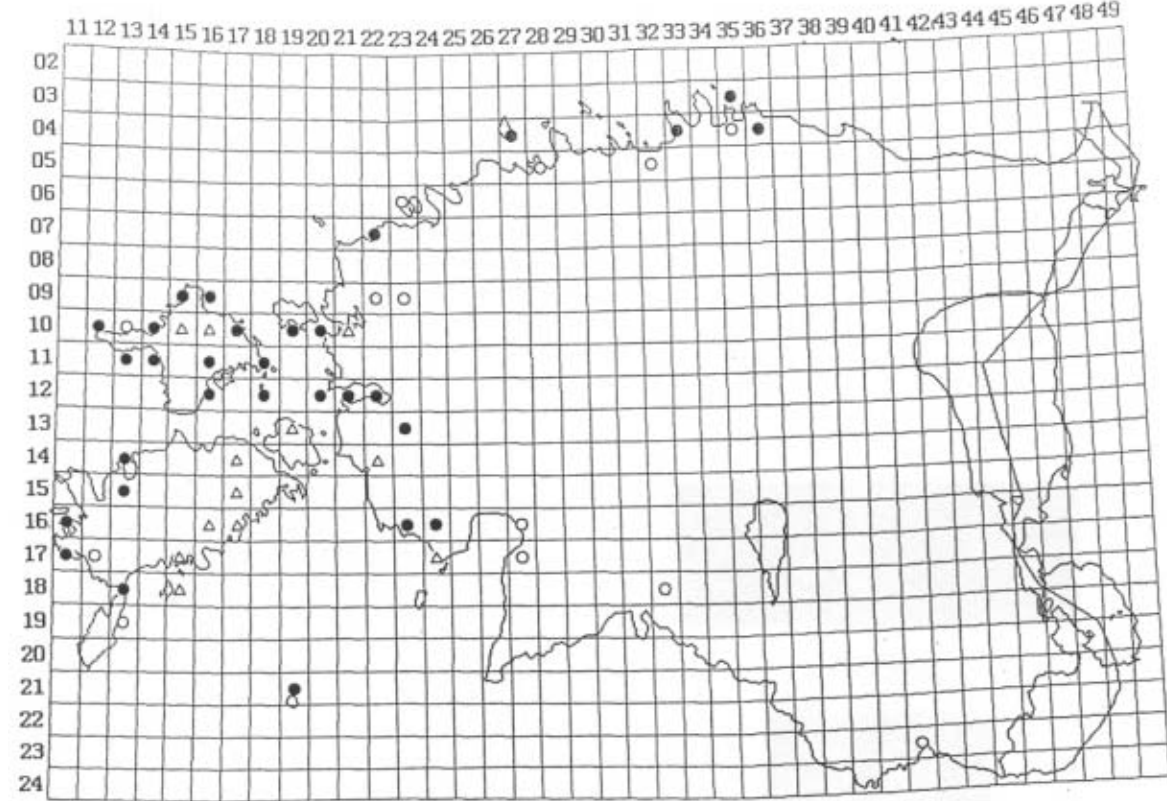

Fig. 1. Distribution of M. laxa ssp. baltica in Estonia (Kukk and Kull 2005).

- findings after 1970; $\bigcirc-1920-1970 ; \Delta-$ before 1920 (herbarium specimens that have been identified later)

\section{Distinctive characters}

Most commonly used characters for distinguishing M. laxa ssp. caespitosa and M. laxa ssp. baltica are duration of life cycle, diameter of corolla, lengths of pedicel and calyx in fruiting stage, length of stem and presence of rosette leaves at the flowering stage (Table 1). 'Typical' individuals, i.e. those most similar to the original taxon descriptions, can be easily separated based on these characters, but many intermediate individuals are commonly found (Apelgren 1990b). Later, Apelgren (1991) treats these intermediate ones as $M$. laxa var. laxa, which in her opinion is a heterogeneous taxon. According to Apelgren (1991) the latter is mostly perennial; calyces and pedicels elongate after flowering, but the length of calyx does not exceed 5 and pedicel $7 \mathrm{~mm}$; branching is extensive and inflorescence is sparse with at least one leaf within it; flowers are of various size and colour.

\section{M. scorpioides}

This was compared to M. laxa as one of the putatively closest taxa, as the subspecies of the latter have been some- times treated as subspecies of $M$. scorpioides (see above) and it belongs to the same series Palustres. The hybridisation of the subspecies of M. laxa between themselves and with $M$. scorpioides has also been hypothesised (Schuster 1967; Przyvara 1986/1987). It is widespread in the northern hemisphere.

\section{Internal transcribed spacer region (ITS) of the nuclear rRNA gene complex}

ITS region is probably the most widely used DNA marker in the angiosperm molecular systematics, particularly at the genus and lower taxonomic levels. Some authors declare that ITS was not the most appropriate marker for systematics, as ITS can be extremely variable within populations and even within individuals because of its multicopy nature (Alvarez and Wendel 2003; Bailey et al. 2003). However, concerted evolution has generally homogenized sequence variation among the numerous ribosomal DNA copies within an individual (Kay et al. 2006). Thus, it still remains the most efficient locus for generating species-le-

TABLE 1. Distinctive characters of M. scorpioides, M. laxa ssp. baltica and M. laxa ssp. caespitosa according to Samuelsson (1926), Schuster (1967), Viljasoo (1969), Grau and Merxmüller (1972), Lazdauskaite et al. (1996) and Ulvinen (1998).

\begin{tabular}{|c|c|c|c|}
\hline Character & M. laxa ssp. baltica & M. laxa ssp. caespitosa & M. scorpioides \\
\hline Duration of life cycle & Annual & Annual, biennial or perennial & $\begin{array}{l}\text { Annual, biennial or (usually) } \\
\text { perennial }\end{array}$ \\
\hline Branching & Rare; occurs at lower part & Strong; occurs at upper part & Branches all over \\
\hline Presence of leaves in inflorescence & Usually present & Usually not present & Usually not present \\
\hline Diameter of corolla & $2-5 \mathrm{~mm}$ & $4-5(6) \mathrm{mm}$ & $6-10 \mathrm{~mm}$ \\
\hline Incisions of calyx & Up to $1 / 2$ & Up to $1 / 2$ & Up to $1 / 3$ \\
\hline Shape of sepals & Oblong-triangular & Oblong-triangular & Triangular \\
\hline Relative length of style & Not longer than calyx & Not longer than calyx & Longer than calyx \\
\hline Length of calyx in fruiting stage & $\begin{array}{l}\text { Up to } 8 \mathrm{~mm} \text {, elongates a lot after } \\
\text { flowering }\end{array}$ & Up to $5 \mathrm{~mm}$, elongates less & Up to $5 \mathrm{~mm}$, elongates less \\
\hline Length of pedicel in fruiting stage & $\begin{array}{l}\text { Up to } 25(35) \mathrm{mm} \text {, much longer } \\
\text { than calyx }\end{array}$ & $\begin{array}{l}\text { Up to } 10 \mathrm{~mm} \text {, not much longer } \\
\text { than calyx }\end{array}$ & Up to $20 \mathrm{~mm}$, longer than calyx \\
\hline Length of fruit & Up to $2.5 \times 1.4 \mathrm{~mm}$ & Up to $1.5 \times 1.0 \mathrm{~mm}$ & Up to $2.0 \times 1.0 \mathrm{~mm}$ \\
\hline Strength of stem & Weak & Strong & Strong \\
\hline Length of stem & Up to $30 \mathrm{~cm}$ & $\mathrm{Up}$ to $50 \mathrm{~cm}$ & Up to $50 \mathrm{~cm}$ \\
\hline Presence of runners & Missing & Missing & Present \\
\hline Condition of the rosette leaves at flowering stage & Usually dead & Usually alive & Usually alive \\
\hline Flowering time & May to July & May to September & May to September \\
\hline
\end{tabular}


vel phylogenetic inferences in most plant groups (Kay et al. 2006) and the results have been mostly congruent with those obtained using other nuclear genes, cDNA or morphology (Judd et al. 2002; Winkworth et al. 2002; Yuan et al. 2004).

ITS sequences have been used for solving phylogenetic relationships in the genus Myosotis and family Boraginaceae (Långström 2002; Winkworth et al. 2002; Hilger et al. 2004). The study of the evolution of the genus Myosotis in the northern and southern hemispheres (Winkworth et al. 2002) included also M. laxa ssp. caespitosa, which appeared in the joint clade with $M$. rehsteineri Wartm. and $M$. debilis Pomel, both originating from Europe (bootstrap support value 96\%). M. laxa ssp. baltica and ssp. laxa were not included in that study. As the ITS region is quite variable in the genus, it should also be suitable for separating subspecies.

\section{Aims}

The aim of this paper is to clarify phylogenetic relationships of M. laxa ssp. caespitosa and M. laxa ssp. baltica and to propose appropriate taxonomic ranks for them. More specifically, we ask:

1) are the two subspecies of M. laxa separate taxa on the basis of the ITS sequences and morphology?;

2) which is the diagnostic value of the morphological characters for distinction of $M$. laxa ssp. caespitosa and $M$. laxa ssp. baltica?;

3) does the morphologically typical M. laxa ssp. baltica occur in Estonia?

\section{MATERIALS AND METHODS}

\section{Materials}

The majority of the herbarium specimens identified as M. laxa ssp. baltica and several identified as M. laxa or M. $l$. ssp. caespitosa were examined from the Estonian (TAA, $\mathrm{TU})$ and Scandinavian herbaria $(\mathrm{S}, \mathrm{H})$, paying special attention to morphologically typical specimens of $M$. laxa ssp. baltica. Loans were asked from B and $\mathrm{K}$ containing $M$. laxa collected from Nordic countries. As mentioned above, type specimen(s) of $M$. laxa ssp. baltica were not chosen by Samuelsson (1926), but material collected and identified by him was examined (from S and B), and the type description was followed (Samuelsson 1926). The material collected by Lehmann from the Herbarium of the Swedish Museum of Natural History (S) was also examined, but the collections did not contain material identified as $M$. laxa. The material used by Lindberg and identified as M. laxa, including specimens from Exsiccatae Fennicae, was examined at the Herbarium of the University of Helsinki $(\mathrm{H})$.

Fresh specimens were collected by E. Kook from Estonia during the years 2002-2003 as follows: 67 specimens of $M$. laxa ssp. caespitosa, 62 specimens of M. laxa ssp. baltica, 20 specimens of $M$. scorpioides and 10 specimens of $M$. arvensis (L) Hill. (mainly from the Island of Hiiumaa and from Western Estonia, Fig. 2). M. arvensis (L.) Hill was included to serve as outgroup in the subsequent analyses. The plants were identified to subspecies caespitosa or subspecies baltica (ssp. laxa was not used), 16 morphological characters (see below) were recorded and leaf samples were collected for DNA extraction. The latter were frozen at $20^{\circ} \mathrm{C}$ and lyophilised with cooling trap Hetotrap CT60 at $60^{\circ} \mathrm{C}$ (in 2002) or dried with silica gel (in 2003). If available, fruits were also collected: 72 fruits from 13 individuals of M. laxa ssp. caespitosa and 78 fruits from 17 individuals of M. laxa ssp. baltica and measured.

\section{Morphological characters}

Morphological characters were chosen from amongst those used in most descriptions and keys or considered to differ between taxa by several authors (Samuelsson 1926; Lindberg 1933; Schuster 1967; Viljasoo 1969; Lazdauskaite et al. 1996; Ulvinen 1998). 14 morphological characters were measured directly (Table 2), two calculated. Fruit length and width were measured using binocular microscope MBS-2 (40x).

\section{Molecular analyses}

DNA was extracted from approximately $0.1 \mathrm{~g}$ of dried leaf tissue using slightly modified (without liquid nitrogen)

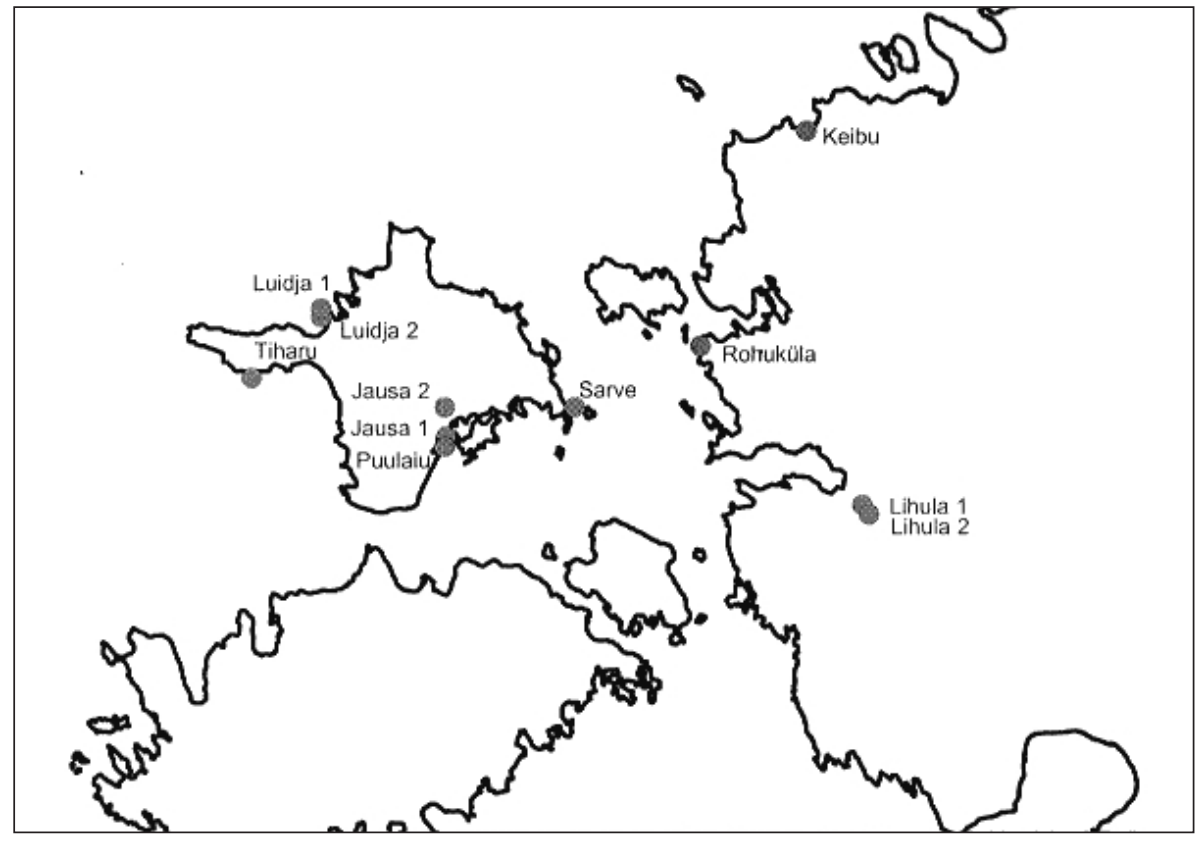

Fig. 2. Map showing the locations in Estonia from where $M$. laxa ssp. caespitosa, M. laxa ssp. baltica, M. scorpioides and $M$. arvensis were collected in years 2002-2003. 
TABLE 2. Measured morphological characters and their states in parsimony analysis.

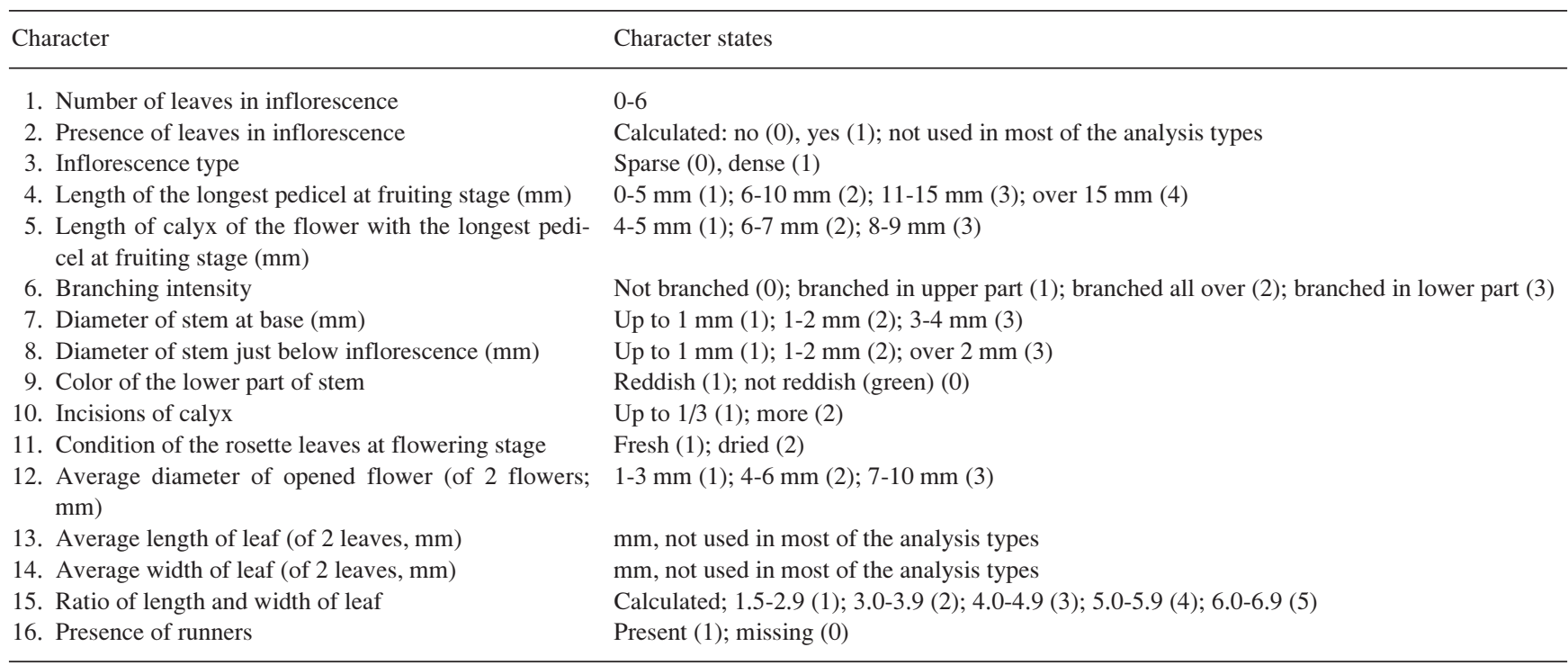

protocol of Doyle and Doyle (1987). PCR was carried out in a total volume of $25 \mu$ l containing $250 \mathrm{mM}$ of each dNTP, $1 \times$ PCR buffer with $\mathrm{MgSO}_{4}$, $1 \mathrm{U}$ Pfu polymerase (MBI Fermentas), 15 pmol of primers ITS4 (5' TCCTCCGCTTATTGATATGC 3') and ITS5 (5'GGAAGTAAAAGTCGTAACAAGG 3'; White et al. 1990), $1 \mu 1$ (1-10 ng) of template DNA, $0.001 \mathrm{mg}$ BSA (bovine serum albumin). Thermocycling was carried out in Mastercycler ${ }^{\circledR}$ Personal (Eppendorf $\mathrm{AG}$ ) using the following reaction conditions: $94^{\circ} \mathrm{C} 2 \mathrm{~min}, 35$ cycles of $94^{\circ} \mathrm{C} 1 \mathrm{~min}, 48^{\circ} \mathrm{C} 1 \mathrm{~min}$, $72^{\circ} \mathrm{C} 1 \mathrm{~min}$, and finally $72^{\circ} \mathrm{C} 10 \mathrm{~min}$. PCR products were purified with nuclease and phosphatase mix Exo-Sap-ITTM (USB Corporation, USA) or UltraClean ${ }^{\mathrm{TM}} 15$ DNA Purification Kit (Mo Bio Laboratories Inc., USA) following the manufacturers' instructions. Sequencing reactions were carried out using Thermo Sequenase ${ }^{\mathrm{TM}}$ Primer Cycle Sequencing Kit (Amersham Biosciences) on sequencer ALFexpress II (Amersham Biosciences). Well readable sequences of the length of 630-684 bp were obtained from 20 specimens (1 M. arvensis, $1 \mathrm{M}$. scorpioides, 7 identified as $M$.

TABLE 3. Voucher specimens. All were collected in Estonia by Ene Kook in 2002 or 2003 and preserved at the Herbarium of the University of Tartu (TU).

\begin{tabular}{|c|c|c|c|c|}
\hline Notation & (Sub)species & Locality & Number in herbarium & Genbank accession number \\
\hline Ja12 & M. laxa ssp. caespitosa & Jausa, Hiiumaa island & TU250127 & EU594642 \\
\hline Ja19 & M. laxa ssp. caespitosa & & TU250121 & EU594643 \\
\hline Ja110 & M. laxa ssp. baltica & & TU250126 & EU594644 \\
\hline Ja113 & M. laxa ssp. baltica & & TU250116 & EU594645 \\
\hline Ja222 & M. laxa ssp. caespitosa & & TU250085 & EU594646 \\
\hline Ja226 & M. laxa ssp. caespitosa & & TU250123 & EU594643 \\
\hline Lu192 & M. laxa ssp. baltica & Luidja, Hiiumaa island & TU250128 & EU594647 \\
\hline Lu196 & M. laxa ssp. baltica & & TU250131 & EU594648 \\
\hline Li134 & M. arvensis & Lihula, Lääne district & TU250132 & EU594649 \\
\hline Li144 & M. laxa ssp. baltica & & TU250129 & EU594650 \\
\hline Li145 & M. laxa ssp. baltica & & TU250120 & EU594651 \\
\hline Ro50 & M. laxa ssp. baltica & Rohuküla, Lääne district & TU250125 & EU594652 \\
\hline Sa157 & M. laxa ssp. baltica & Sarve, Hiiumaa island & TU250130/3 & EU594653 \\
\hline Sa158 & M. laxa ssp. baltica & & TU250130/4 & EU594653 \\
\hline Sa167 & M. laxa ssp. caespitosa & & TU250140 & EU594659 \\
\hline Sa169 & M. laxa ssp. caespitosa & & TU250124 & EU594654 \\
\hline Ti69 & M. scorpioides & Tiharu, Hiiumaa island & TU250240 & EU594655 \\
\hline Ti72 & M. laxa ssp. baltica & & TU250087 & EU594656 \\
\hline Ti73 & M. laxa ssp. baltica & & TU250122 & EU594658 \\
\hline Ti82 & M. laxa ssp. caespitosa & & TU250084 & EU594657 \\
\hline
\end{tabular}


laxa ssp. caespitosa, 11 identified as M. laxa ssp. baltica). The voucher specimens with notations and GenBank (http://www.ncbi.nlm.nih.gov/entrez/query.fcgi?DB=pubmed) accession numbers for their sequences are listed in Table 3.

\section{Data analysis}

Characters not having normal distribution were logtransformed; number of leaves in inflorescence was standardized. Morphological data were analysed using principal components analysis, stepwise discriminant analysis, and analysis of variance (ANOVA) defining subspecies as a factor implemented in package STATISTICA 6.0 (Stat Soft Inc. 2001). For comparison of means, Student's t-test and Tukey test were used. For characters 2, 3, 9, 10, 11 and 16 (Tables 2 and 3) nonparametric Kruskal-Wallis ANOVA was performed. For cluster analysis, the average values of morphological characters by subspecies in populations were used and UPGMA with Manhattan distance performed with the same program package. $M$. arvensis was not included in these analyses.

Fruit data were available for only small number of individuals, because in most of the populations fruits were not ripe at the time of specimen collection. Therefore fruit data were analysed separately and t-test carried out.

DNA sequences were processed and complementary strands aligned using ALFwin ${ }^{\mathrm{TM}}$ Sequence Analyser 2.00 (Amersham BioSciences). These together with earlier sequenced representatives from GenBank were aligned using ClustalW and corrected manually in BioEdit (Hall 1999). We included Myosotis rehsteineri Wartm. ex Reut. as the closest sister species of $M$. laxa ssp. caespitosa according to Winkworth et al. (2002), other related sequenced taxa from Europe and one species from every major branch of the phylogenetic tree of Myosotis. Myosotis taxa most distantly related to $M$. laxa ssp. caespitosa (M. australis, $M$. cadmea, $M$. discolor, $M$. personii, and $M$. verna) were used as outgroup. Gaps in the beginning and/or end of some sequences were treated as missing data. Phylogenetic analyses were implemented in PAUP 4.0b10 (Swofford 2002) as follows: 1) parsimony analysis with heuristic search, treebisection-reconnection (TBR) and multiple parsimony

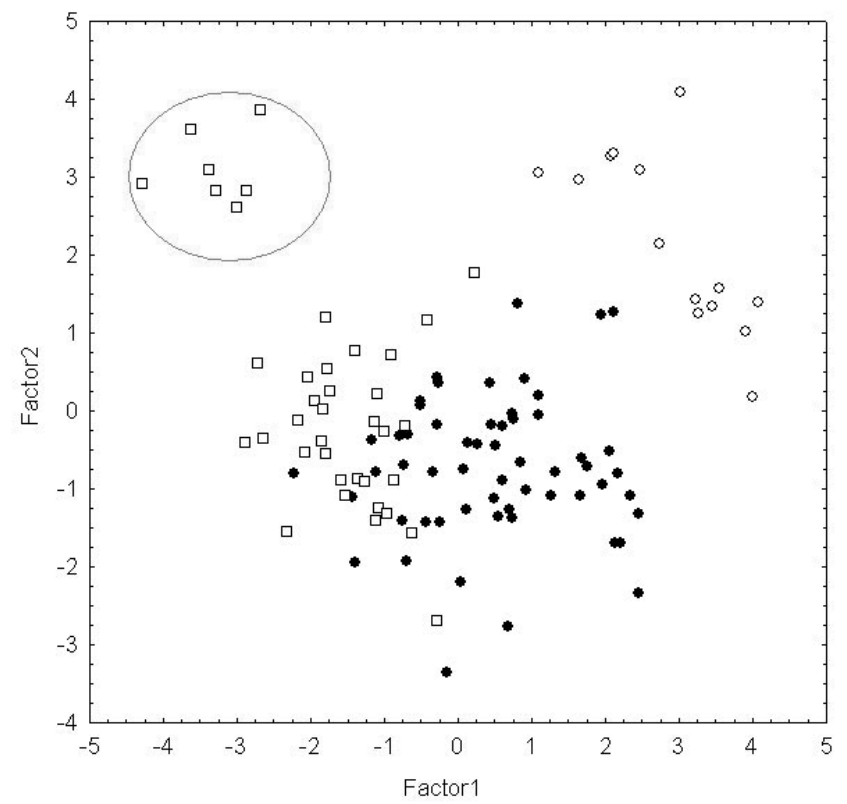

(MULPARS) options; and 2) neighbour joining analysis with the Hasegawa, Kishino and Yano (1985) model (HKY85), which estimates a transition-transversion ratio, takes into account base frequencies and thus generalizes the other models. The relative support for the clades was determined by bootstrap analysis employing 100 replicates (Felsenstein 1985).

Genetic differentiation between subspecies and populations of M. laxa was estimated using hierarchical AMOVA (analysis of molecular variance) implemented in Arlequin 2.000 (Schneider et al. 2000). Significance of differentiation was assessed using permutation tests. For estimating pairwise genetic distances, $\mathrm{F}_{\mathrm{ST}}$, an estimate of differentiation based on allele frequencies, was calculated. This parameter can be used as distance between populations (Schneider et al. 2000).

\section{RESULTS}

\section{M. laxa ssp. baltica in herbaria and typification of the name Myosotis baltica Sam}

Five specimens seen from the collection of Samuelsson collected from Sweden (1925-1932) stored in the herbarium of the Swedish Museum of Natural History (S), appeared to match the original species description, i.e. were typical. Seven specimens from Kew herbarium (K) and two specimens from Berlin herbarium (B), collected from Sweden, belonged also to the ssp. baltica according to the type description. One of the specimens from the collection of Samuelsson kept in B (collected in 1929, B 10 0151942!) has been designated by Dickoré in 1988 as possible type material with question mark (note on the herbarium specimen), but was not officially typified and is not suitable for lectotype. The specimens mentioned by Lindberg (1915) and classified as $M$. laxa, including the specimens from Exsiccatae Fennicae also corresponded to the type description of Samuelsson (1926) as well as to the description of $M$. laxa by Lehmann (1818). The only specimens from Samuelsson's original material suitable for lectotypification are from S! collected in 1925 from Uppland, Sweden. All Samuelsson's other specimens (S!,B!) were collected at
- M. I. ssp.caespitosa 口 M. I. ssp. baltica - M. scorpioides
Fig. 3. Principal components analysis of morphological characters of $M$. laxa ssp. $c a$ espitosa, M. laxa ssp. baltica and $M$. scorpioides. Factors 1 and 2 describe $26.8 \%$ and $18.0 \%$ of the variability (eigenvalues 3.2 and 2.2), respectively. The typical M. l. ssp. baltica specimens are encircled. 
a later date. The typification and synonymy can be thus summarized:

M. laxa Lehm. ssp. baltica (Sam.) Hyl. ex Nordh., Norsk Fl. 529 (1940)

$\equiv$ M. baltica Sam. (in Lindm.), Sv. Fan. Fl. 458 (1926)

- Lectotype (designated here): Uppland, Rådmansö Hamnskär i Lygne skärgård, 12/7 1925 G. Samuelsson S HS-6990! Isolectotype: Uppland, Rådmansö Hamnskär i Lygne skärgård, 12/7 1925 G. Samuelsson S HS-6991!

$\equiv$ M. laxa var. baltica (Sam.) Apelgren, Acta Univ. Ups. 306: 21 (1991)

= M. laxa Lehm., Pl. Asperif. I: 83 (1818) sensu auct. (Lindberg 1915, 1934; Schuster 1967)

$=$ M. laxa Lehm. ssp. laxa s.1., sensu auct. (Lid and Lid 1994)

= M. scorpioides L. em. Hill. ssp. laxa (Lehm.) Hegi, Ill. Fl. Mitteleur. 2165 (1927)

Occurrence of morphologically typical M. laxa ssp. baltica in Estonia

20 morphologically typical specimens of M. laxa ssp. baltica collected from Estonia were found from the local herbaria (TU, TAA). The oldest specimen was collected in 1932 from northern Estonia. The specimens found in Estonia were very similar to those collected and identified by Samuelsson. 21 typical individuals of M. laxa ssp. baltica were collected during the field works from four populations in Estonia (Rohuküla, Sarve, Puulaiu, and Tiharu see Figure 3). The habitats of these were also typical, i.e. on the seashore close to the water.

\section{Morphological characters}

Principal component analysis of morphological characters of M. scorpioides, M. laxa ssp baltica and M. laxa ssp. caespitosa showed that $M$. scorpioides can be well discriminated from M. laxa s.l. (Fig 3). A group of typical M. laxa ssp. baltica separates very clearly from $M$. laxa ssp. caespitosa, but most of the specimens of the two subspecies are not distinguishable.

A similar result was obtained in UPGMA analysis that revealed some well-defined clusters: cluster 2 (Fig. 4) comprises both $M$ scorpioides populations; clusters 1 and 3 contain morphologically more or less typical M. laxa ssp. baltica populations; the largest cluster 4 contains both subspecies of M. laxa, mostly M. laxa ssp. caespitosa.

M. scorpioides was $95 \%$ correctly classified according to the discriminant analysis, but subspecies of $M$. laxa were not well discriminated (Table 4).

Among the 16 analysed morphological characters, 14 proved usable for differentiation of the three studied taxa; only length and width of leaves were not informative (Table 5). Nine characters were statistically significantly different between $M$. laxa ssp. baltica and M. laxa ssp. caespitosa and thus can be used for taxon distinction: length of pedicel, length of calyx, colour of stem, inflorescence type (dense or sparse), branching, presence and number of leaves in inflorescence, rosette leaves fresh or dried at flowering stage and diameter of stem at base (Fig. 5). The means of the character values are presented in Table 5. When the analysis was performed by populations, the variation of several characters overlapped largely for different taxa from some populations, while in other populations the differences were clear (data not shown).

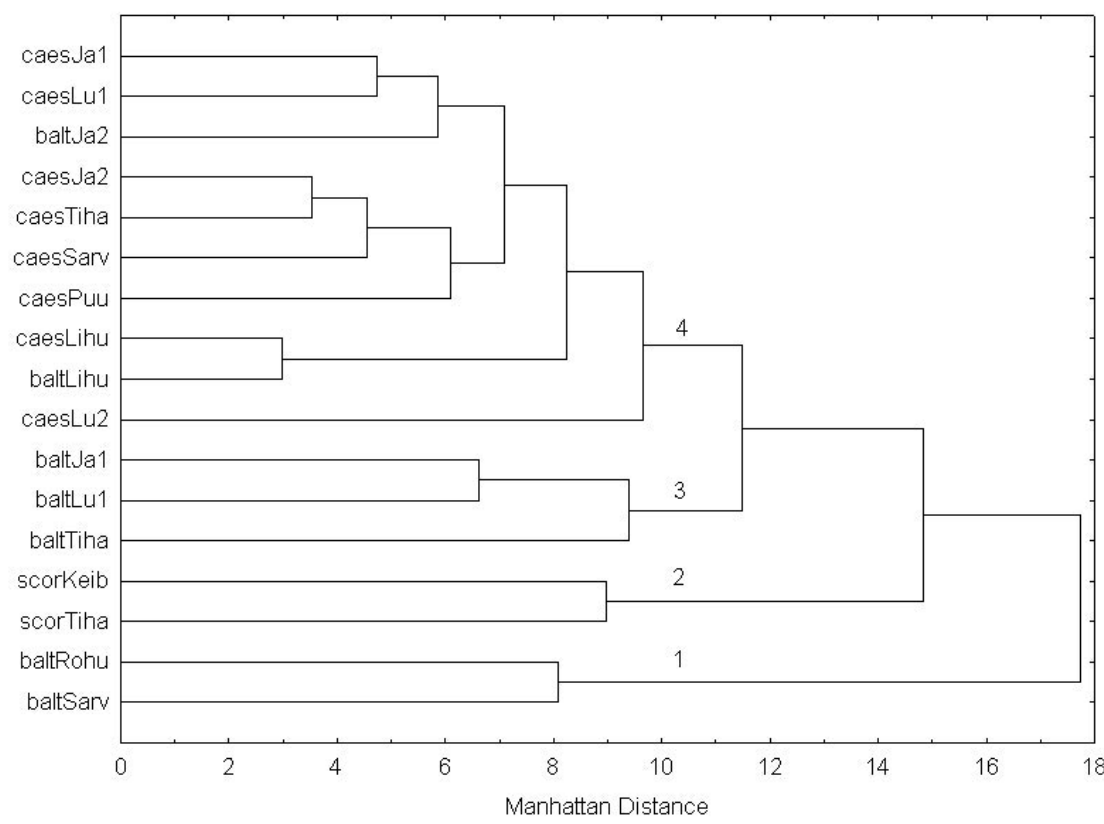

Fig. 4. UPGMA analysis of morphological characters by populations (Manhattan distance). The populations are coded as follows: taxon (caes-M. laxa ssp. caespitosa, balt- $M$. laxa ssp. baltica and scor-M. scorpioides); site (Tiha-Tiharu, Sarv-Sarve, Lu-Luidja, Lihu-Lihula, Puu-Puulaiu, Ja-Jausa, Rohu-Rohuküla, Keib-Keibu, see Figure 2); population number (if several in neighbourhood).

TABLE 4. The classification matrix for M. scorpioides, M. laxa ssp. baltica and ssp. caespitosa obtained by discriminant analysis. Observed identification is presented in rows, classification predicted by the analysis is given in columns.

\begin{tabular}{lccc}
\hline Taxon & Percent correct & M.l. ssp. caespitosa & M. l. ssp. baltica \\
\hline M. l. ssp. caespitosa & 85.1 & 57 & 10 \\
M. l. ssp. baltica & 95.2 & 3 & 60 \\
M. scorpioides & 95.0 & 1 & 0 \\
\hline
\end{tabular}


TABLE 5. Results of ANOVA or Kruskal-Wallis tests by species and average values of morphological characters

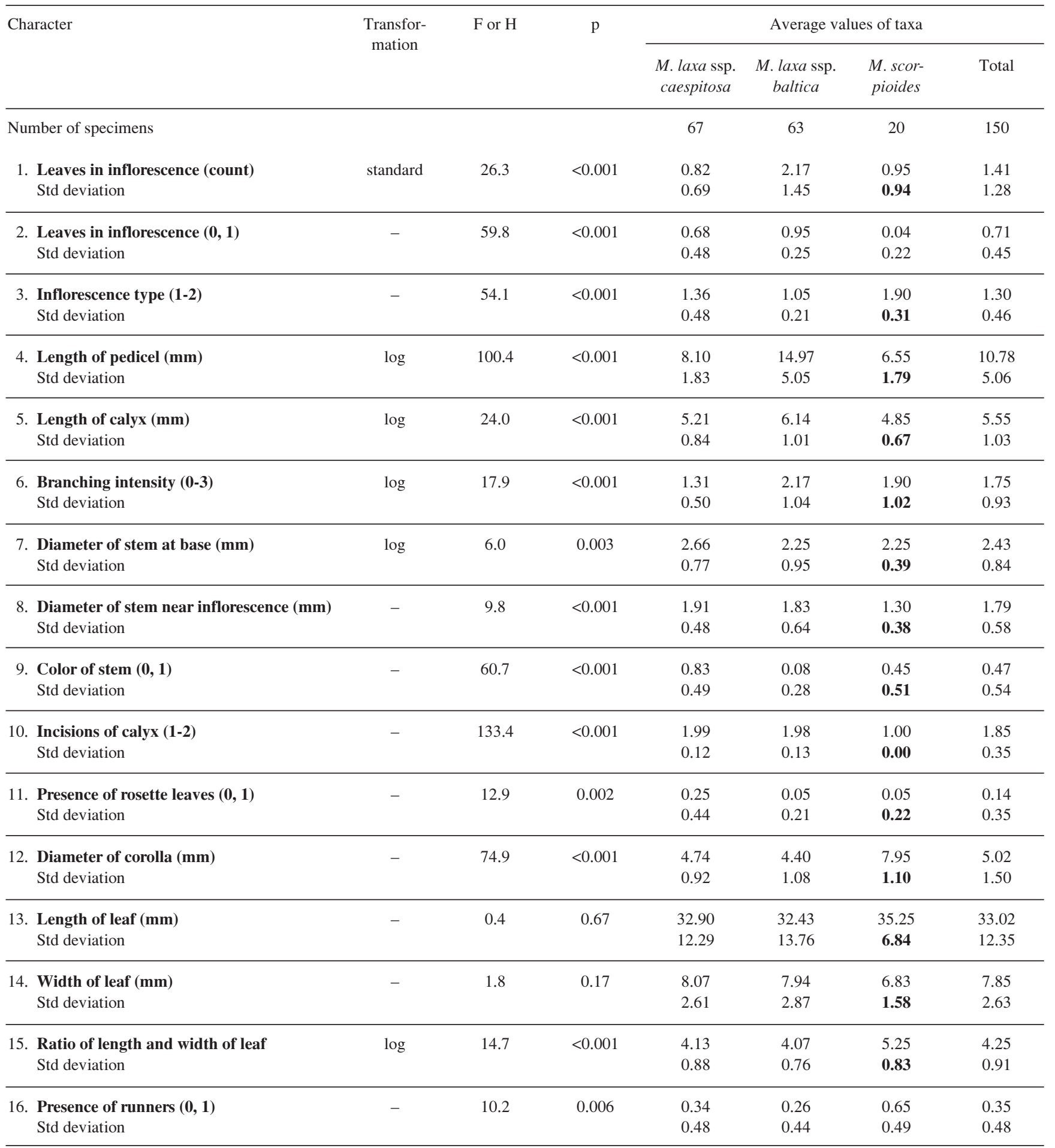

Fruits of $M$. laxa ssp. baltica were significantly longer than these of ssp. caespitosa (Fig. 6, Table 6). The difference in width was not statistically significant. However, if analysed by populations, fruits of the morphologically typical ssp. baltica from Rohuküla population were significantly wider than these of specimens of the same subspecies from other populations $(\mathrm{t}=-4.24 ; \mathrm{p}=0.0007$; data not shown). In general, fruits of M. laxa ssp. baltica were slightly smaller than expected based on previous data from literature (see Tables 1 and 6).

\section{Analysis of the ITS sequences}

Heuristic analysis of parsimony found 269 shortest trees, using 621 characters (nucleotides), of which 504 were con- stant, 45 non-informative and 72 informative. The shortest trees after iterative weighting of characters had 132 steps, the indices were $\mathrm{CI}=0.86, \mathrm{HI}=0.14$ and $\mathrm{RI}=0.90$. The topology of the neighbour joining tree was similar to that of parsimony analysis and only the NJ phylogram is presented. M. laxa s.l. formed a monophyletic group that included $M$. rehsteineri and $M$. scorpioides (Fig. 7) with bootstrap support of $94 \%$, or $55 \%$ if excluding $M$. scorpioides. Within that group three subclades can be recognised: one containing a single specimen of $M$. scorpioides, other specimens of both subspecies of M. laxa from Sarve population and the largest one all other specimens, including $M$. rehsteineri. Morphologically typical specimens of M. laxa ssp. baltica (e.g., Ro50 and Sa157) were grouped into different 

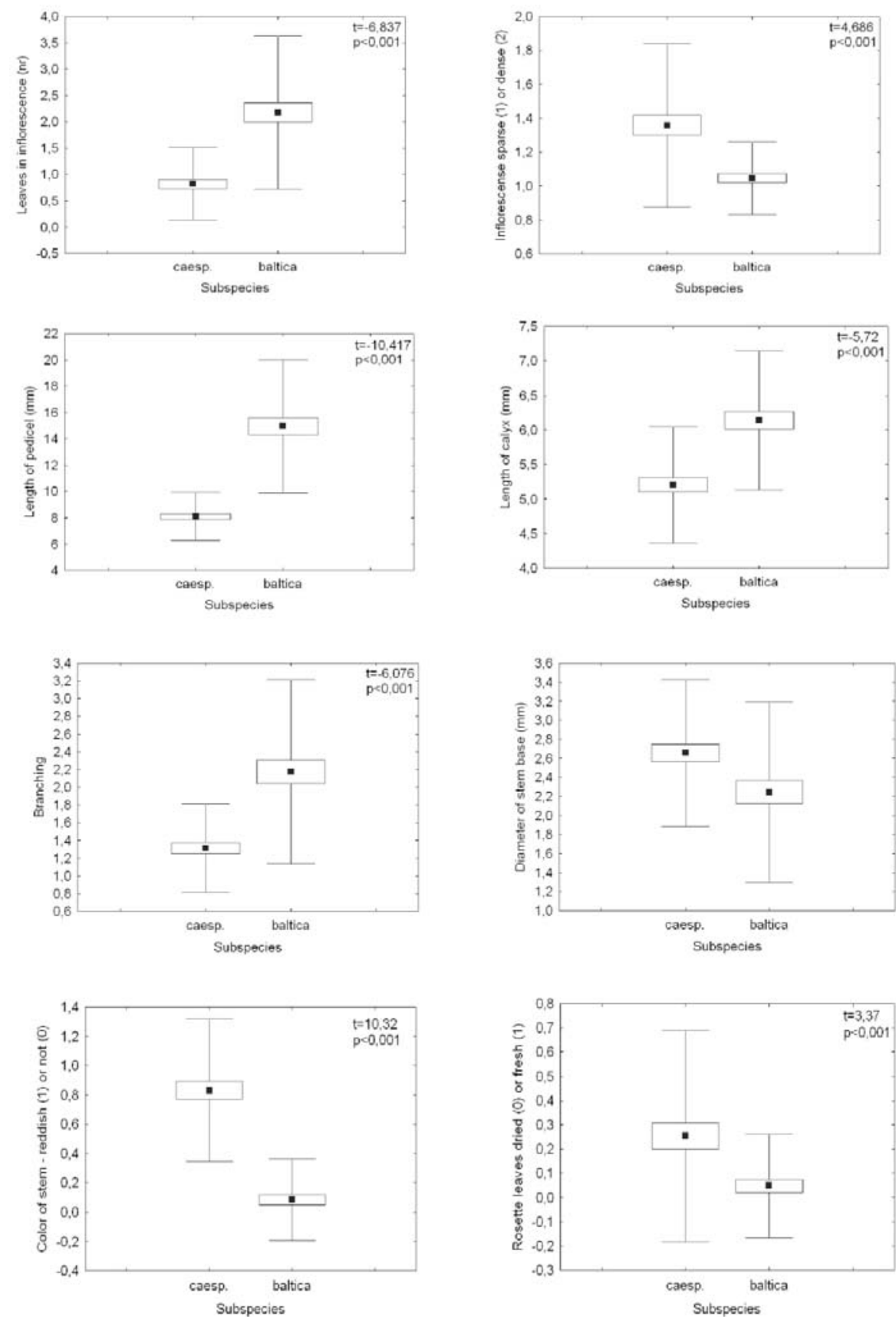

Fig. 5. Means $\square$, standard errors $\square$ and standard deviations I of morphological characters which show statistically significant difference between $M$. laxa ssp. caespitosa and M. laxa ssp. baltica. Presence of leaves in inflorescence is not shown because it is highly correlated with the number of leaves in inflorescence.

TABLE 6. Average values of fruit length and width of M. laxa ssp. baltica and M. laxa ssp. caespitosa.

\begin{tabular}{lccccc}
\hline Subspecies & Specimens & Fruits & $\begin{array}{c}\text { Average length } \\
(\mathrm{mm})\end{array}$ & $\begin{array}{c}\text { Standard } \\
\text { deviation }\end{array}$ & $\begin{array}{c}\text { Average width } \\
(\mathrm{mm})\end{array}$ \\
\hline M. laxa ssp. baltica & 17 & 78 & $\mathbf{1 . 5 7}$ & 0.11 & $\mathbf{1 . 1 3}$ \\
M. laxa ssp. caespitosa & 13 & 72 & $\mathbf{1 . 4 3}$ & 0.15 & $\mathbf{1 . 0 5}$ \\
Total & 30 & 150 & $\mathbf{1 . 5 0}$ & 0.09 & $\mathbf{1 . 0 9}$ \\
\hline
\end{tabular}

clades. No clear grouping based on populations can be observed, except a clade containing specimens from the Sarve population with bootstrap support of $58 \%$. M. arvensis sequenced by us (aLi134) grouped together with $M$. arvensis sequenced by Winkworth et al. (2002) in a well supported cluster close to the outgroup (bootstrap support 100\%).

AMOVA yielded negative variance components at the hierarchical level of species (Table 7). The AMOVA methodology relies on estimates of relationships between alleles in the same population or group of populations relative to alleles of different populations or groups of populations (Weir 1996). Negative variance components can result from very small, but positive estimates of genetic structure indices from data (Weir 1996). This implies that alleles are more related between than within species and most of the variability occurs within species, between and within populations. Pairwise genetic distances between the subspecies $\left(\mathrm{F}_{\mathrm{ST}}=-0.04 ; \mathrm{p}=0.64\right)$ and populations (data not shown) were not significant. 

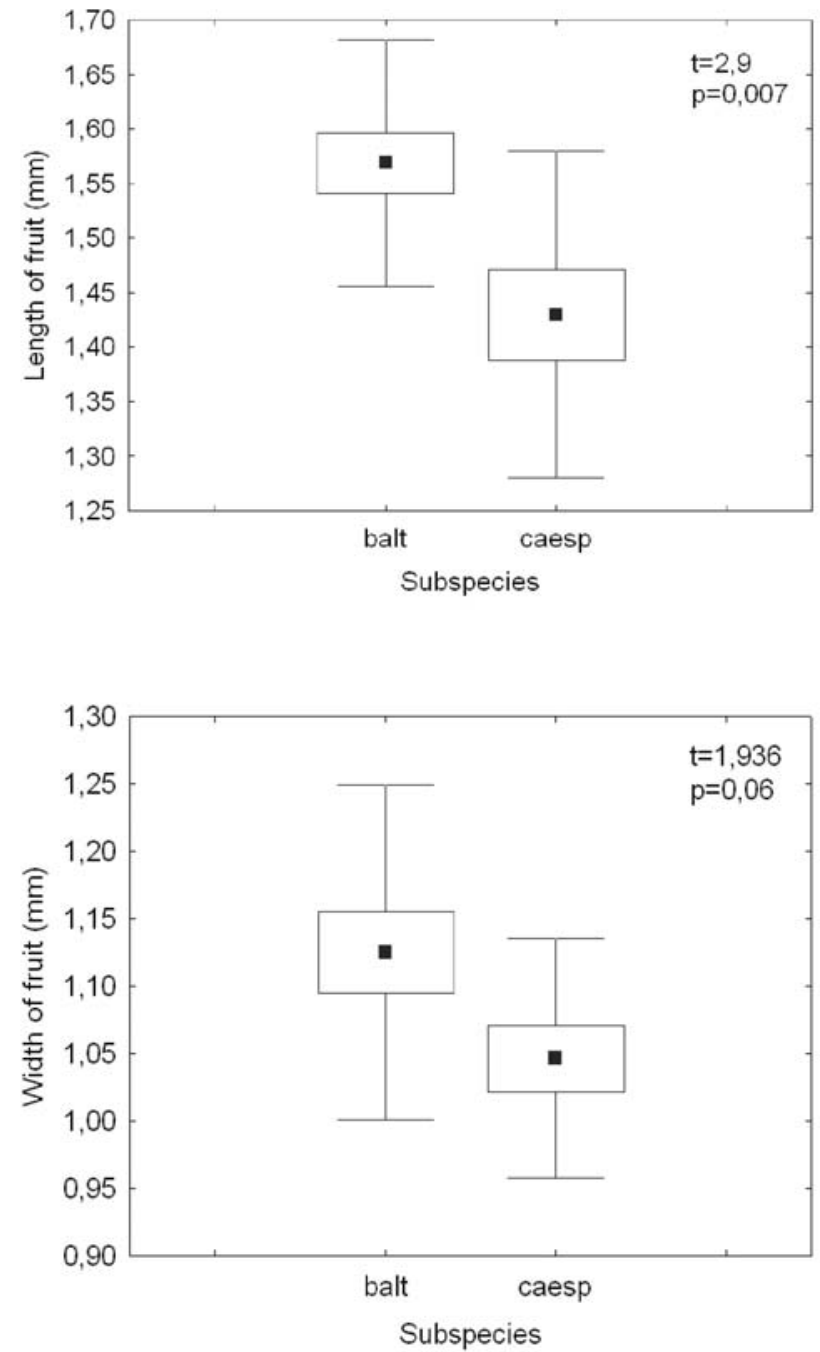

Fig. 6. Means $\square$, standard errors $\square$ and standard deviations $I$ of width and length of fruit of the subspecies of M. laxa.

\section{DISCUSSION}

The status of the three subspecies of M. laxa is unclear and the history of the intraspecific taxa is very confusing. None of the taxa has been typified before. Therefore, having seen the original material of M. laxa ssp. baltica by Samuelsson, we typified that taxon. However, in our opinion, Lindberg $(1915,1933)$ was right that the description of M. laxa (Lehmann 1818), though described from North America, corresponds rather well with that of M. laxa ssp. baltica. It is not well understandable why Samuelsson (1926), describing M. baltica as a separate species, declared that this new species is neither M. laxa sensu Lehmann nor sensu Lindberg, while his description does not differ at all from the characterization of coastal $M$. laxa by Lindberg (1915) and is very similar to the description of M. la$x a$ by Lehmann (1818). Lindberg (1934) considered that this could be lapsus calami by Samuelsson. The separation of M. laxa ssp. caespitosa, at least at the level of variety or subspecies, seems reasonable, because typical subspecies caespitosa is morphologically well distinct from subspecies baltica, as also confirmed by our data. However, there are specimens showing a range of variation, which cannot be clearly classified into either of the two above-mentioned subspecies. The range of variation can be seen particularly clearly if both subspecies occur at the same site. The only clearly distinguishing character is the length of pedicel at the fruiting stage.

Apelgren (1991) found a solution in declaring that the third subspecies, M. laxa ssp. laxa, considered occurring only in America by most floras and identification keys, includes the intermediate specimens and grows also in Eurasia. It is somehow understandable, as there are some records of baltica- or laxa-like plants from several parts of Eurasia (Schuster 1967; Saiki and Osegawa 1972). We have seen such baltica-like herbarium specimens (TU) from Kiev (Ukraine), Tula and Kamchatka (Russia). However, the separation of the subspecies baltica and laxa is almost impossible, as there are no types, ssp. laxa is morphologically very variable and its description largely overlaps with that of ssp. baltica. Although Apelgren (1991) lowers the taxonomic rank of all three taxa to variety, there still seem to be too many units within the species.

Our data, both morphological and molecular, did not support clear distinction of subspecific taxa, neither two nor three. ITS-sequence analysis showed that M. laxa $s$. $l$. together with $M$. rehsteineri is monophyletic with bootstrap support of $94 \%$, but neither M. laxa ssp. caespitosa nor $M$. laxa ssp. baltica is monophyletic. It is possible, that $M$. rehsteineri also belongs to the complex. The latter has been treated as a variety $M$. caespitosa var. grandiflora Gaudin (Schuster 1967), and was recently positioned as a sister taxon of M. laxa ssp. caespitosa (Winkworth et al. 2002). This species should also be included in further research.

Although phylogenetic analysis performed with morphological characters supported the monophyly of ssp. baltica, the ITS-sequence data did not support this. Phylogenetic relationships within $M$. laxa $s$. $l$. are largely unresolved. According to AMOVA the genetic variability within subspecies was much more extensive than between them and genetic distance between species was not significant, thus the subspecies cannot be distinguished by ITS-sequences.

Comparison of the herbarium specimens and freshly collected material from Estonia with authentic material of Samuelsson, as well as with the type description, provides evidence that the morphologically typical M. laxa ssp. bal-

TABLE 7. AMOVA analysis results for subspecies of $M$. laxa $\left(\mathrm{F}_{\mathrm{st}}=0.32 ; \mathrm{p}=0.002\right)$, based on pairwise differences. $\mathrm{F}_{\mathrm{st}}$ significance test based on 1023 permutations.

\begin{tabular}{lccc}
\hline Source of variation & d.f. & Sum of squares & Variance components \\
\hline Between subspecies & 1 & 0.88 & -0.16 \\
Within subspecies (between populations) & 7 & 13.12 & 0.56 \\
Within populations & 9 & 7.50 & 0.83 \\
\hline Total & 17 & 21.50 & 45.36 \\
\hline
\end{tabular}




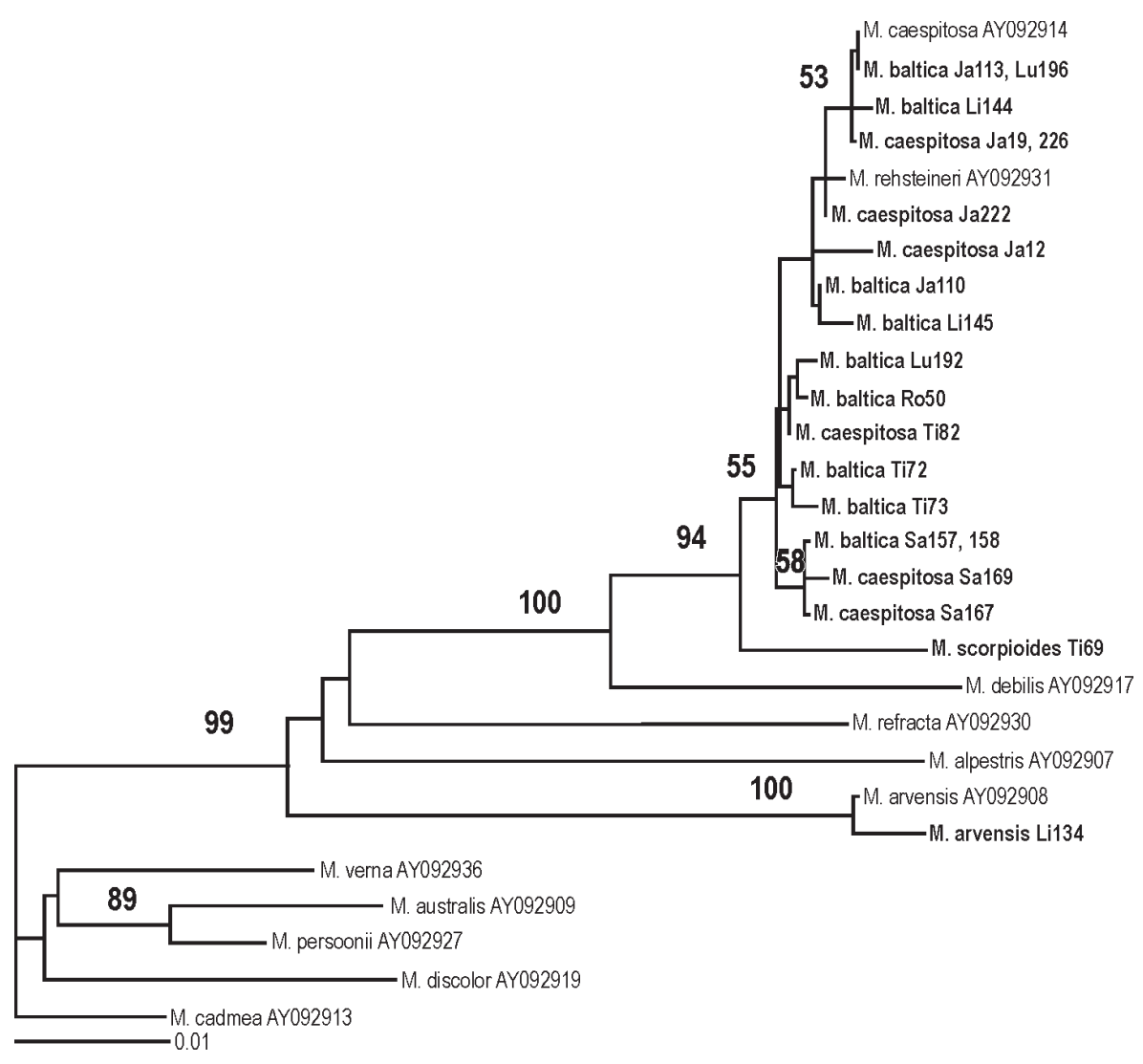

Fig. 7. Neighbour joining analysis with HKY85 distance of nuclear ribosomal ITSsequences of study specimens (bold) and related GenBank accessions. Bootstrap values $>50 \%$ are shown above the branches. The accession numbers, habitat codes and voucher specimens of the analysed specimens are shown in Table 3. The identical sequences were analysed together as one, the code then consists of several accession numbers. Sequences from GenBank are denoted with their GenBank codes. M. australis, $M$. cadmea, $M$. discolor, M. personii, and $M$. verna were used as an outgroup. tica does occur in Estonia, as well as in Sweden and Finland. Our results of the analyses of morphological characters are similar to the earlier results (Apelgren 1990b) in sense that there are both typical specimens and intermediate ones, often present at the same locality. Consequently the wide range of morphological variability of M. laxa s. $l$. including typical ssp. baltica occurs in Estonia as well as in Finland and Sweden. Analysis of morphological characters revealed that specimens classified as M. laxa ssp. baltica are more variable than these identified as M. laxa ssp. caespitosa. We hypothesise that there is one circumpolar species M. laxa with ecotypes or varieties, but the intraspecific taxa are not distinct. Thus, treating them as subspecies is not recommended and as species is not acceptable. As generally thought, subspecies should differ morphologically and/or genetically and have at least slightly separate distribution ranges. However, trees of individual genes may differ from the tree of taxa, especially in the case of reticulate evolution. Thus further investigation including all putative taxa of M. laxa as well as M. rehsteineri, wider geographical sampling together with different molecular markers, including chloroplast DNA is needed to clarify completely the position of these taxa.

Furthermore, we question the theory that $M$. laxa ssp. baltica is an endemic that originates from Aland and has spread from there around the Baltic Sea by streams (Apelgren 1990b). Firstly, the streams in the Baltic Sea are dependent on winds, temperature, air pressure, water level, inflow from rivers, vertical circulation and other factors; therefore the flow at any point and at any time can be from a variety of directions (Astok and Mardiste 1995). Thus, we cannot say that the seeds can travel only counter-clockwise in the Baltic Sea. Secondly, the theory would imply that $M$. laxa ssp. caespitosa is 'native' in Estonia and $M$. laxa ssp. baltica arrived later from Sweden. The latter should therefore be monophyletic and genetically distinct from the former. As it is not so, we should consider M. laxa ssp. baltica as an ecotype adapted to coastal habitats with fluctuating conditions. Such adaptation has probably appeared several times in evolution in different regions of the Baltic Sea and may well do so in the future. The fact that it is less common in other regions compared to Åland could also be determined by the environmental conditions: other regions do not have so extensive land lifting as Aland and the coast of the Gulf of Bothnia (Ericson and Wallentinus 1979). As M. laxa ssp. baltica can be separated from M. laxa ssp. caespitosa neither by ITS-sequences nor by morphological characters, might its taxonomic rank even be lowered to variety as already proposed by Apelgren (1991).

\section{ACKNOWLEDGEMENTS}

We express our gratitude to MSc Irja Saar for help with sequencing, and to Dr Vello Jaaska, Dr Tiina Randlane, an anonymous reviewer and our English teacher J. Uhler for valuable comments during the preparation of the manuscript. We are thankful to herbaria (TU, TAA, H, K, B, S) for visits and loans, especially to Prof. P. Uotila from the Finnish Museum of Natural History and Dr. T. Karlsson from the Swedish Museum of Natural History, who besides helping with herbarium materials gave useful advice. The research was financed by the Estonian Science Foundation grant nr 5815 and the state program "Collections of humanities and natural sciences" for years 2004-2008.

This research was also supported by the European Union throught the European Regional Development Fund (Centre of Excellence FIBIR). 


\section{LITERATURE CITED}

ALHONEN P. 1966. Baltic Sea. In: Fairbridge R. The Encyclopedia of Oceanography. Van Nostrand Reinhold Company, New York, pp. 87-91.

ALVAREZ I., WENDEL J.F. 2003. Ribosomal ITS sequences and plant phylogenetic inference. Molec. Phylog. Evol. 29: 417-434.

APELGREN K. 1986. Några problematiska Myosotis-arter vid Östersjön. Svensk Bot. Tidskr. 80: 145-150.

APELGREN K. 1990a. Myosotis baltica - a questionable taxon. Sommerfeltia 11: 5-11.

APELGREN K. 1990b. Variation and distribution of Myosotis la$x a$ sensu lato (Boraginaceae) in the Baltic region. Ann. Bot. Fenn. 27: 287-299.

APELGREN K. 1991. Relations between coast and inland taxa in the Baltic region: case studies in Galium palustre s. lat. and Myosotis laxa s. lat. Acta Univ. Upsal. 306: 1-33.

ASTOK V., MARDISTE H. 1995. Läänemeri ja tema arengulugu. 2. Nüüdismeri. In: Raukas A. (ed.), Eesti: Loodus. Valgus, Tallinn, pp. 228-237.

BAILEY C.D., CARR T.G., HARRIS S.A., HUGHES C.E. 2003. Characterization of angiosperm nrDNA polymorphism, paralogy and pseudogenes. Molec. Phylog. Evol. 29: 435$-455$.

BASKIN C.C., BASKIN J.M. 1998. Seeds. Ecology, Biogeography and Evolution of Dormancy and Germination. Academic Press, San Diego.

BRITTON N.L., BROWN H.A. 1898. Illustrated Flora of the Northern United States, Canada and British Possessions, Vol. 3. Charles Scribner's Sons, New York

CEPURFTE B. 2003. Vascular Flora of Latvia: Boraginaceae (Borage family), Verbenaceae (Vervain family). University of Latvia, Riga.

DOYLE J.J., DOYLE J.L. 1987. A rapid DNA isolation procedure for small quantities of fresh leaf tissue. Phytochem. Bull. 19: 11-15.

ERICSON L., WALLENTINUS H.-G. 1979. Sea-shore vegetation around the Gulf of Bothnia. Guide for the International Society for Vegetation Science July-August 1977. Wahlenbergia 5: 1-142.

FELSENSTEIN J. 1985. Confidence limits on phylogenetics: an approach using the bootstrap. Evolution 39: 783-791.

GRAU J., MERXMÜLLER H. 1972. Myosotis L. In: Tutin T.G., Heywood V.H., Burges N.A., Moore D.M., Valentine D.H., Walters S.M., Webb D.A (eds), Flora Europea, vol. 3. Cambridge University Press, Cambridge, pp. 111-117.

GRAU J., SCHWAB A. 1982. Mikromerkmale der blüte zur Gliederung der Gattung Myosotis. Mitt. Bot. Staatssamml. München 18: 9-58.

HALL T.A. 1999. BioEdit: a user-friendly biological sequence alignment editor and analysis program for Windows 95/98/NT. Nucleic Acids Symposium Series 41: 95-98.

HARPER J.L. 1977. Population Biology of Plants. Academic Press, London.

HASEGAWA M., KISHINO H., YANO T. 1985. Dating of the human-ape splitting by a molecular clock of mitochondrial DNA. J. Mol. Evol. 22: 160-174.

HEGI G. 1927. Illustrierte Flora von Mittel-Europa. Vol. 5. Carl Hanser Verlag, München.

HILGER H.H., SELVI F., PAPINI A., BIGAZZI M. 2004. Molecular Systematics of Boraginaceae tribe Boragineae based on ITS 1 and trnL sequences, with special reference to Anchusa s.1. Ann. Bot. 94: 201-212.

HULTÉN E., FRIES M. 1986. Atlas of North Europaean Vascular Plants, vol. 2. Fuldaer Verlagsanstalt GmbH, Fulda.

INGELÖG T., ANDERSSON R., TJERNBERG M. (eds). 1993. Red Data Book of the Baltic Region. Swedish Threatened Species Unit, Uppsala.
JONSELL B. 1988. Mikroendemism i det baltiska landhöjningsområdet. Blyttia 46: 65-73.

JUDD W.S., CAMPBELL C.S, KELLOGG E.A., STEVENS P.F., DONOGHUE M.J. 2002. Plant Systematics: A Phylogenetic Approach. Second Edition. Sinauer Associates Inc., Sunderland.

KAY K.M., WHITTALL J.B., HODGES S.A. 2006. A survey of nuclear ribosomal internal transcribed spacer substitution rates across angiosperms: an approximate molecular clock with life history effects. BMC Evol. Biol. 6: 36.

KROK T.O.B.N., ALMQUIST S. 1994. Svensk Flora. Fanerogamer och ormbunksväxter. Liber $\mathrm{AB}$, Stockholm.

KUKK T., KULL T. 2005. Eesti taimede levikuatlas. Atlas of the Estonian Flora. EMÜ põllumajandus - ja keskkonnainstituut, Tartu.

KUPFFER K.R. 1925. Grundzüge der Pflanzengeographie des Ostbaltischen Gebietes. In: Abhandlungen des Herder-Instituts zu Riga, Bd. 1. Herder-Institut zu Riga, Riga, pp. 1-224.

LÅNGSTRÖM E. 2002. Systematics of Echiochilon and $O g a-$ stemma (Boraginaceae), and the phylogeny of Boraginoideae. Acta Univ. Upsal. 693: 1-34.

LAZDAUSKAITE Z., VILJASOO L., CEPURITE B. 1996. Myosotis L. In: Kuusk V., Tabaka L., Lekavicius A. (eds), Flora of the Baltic Countries, vol. 2. Eesti Loodusfoto, Tartu, pp. 280$-282$.

LEHMANN J.G.C. 1818. Plantae e familia Asperifoliarum nuciferae. P.1. Sumptibus F. Dümmler, Berlin.

LID J., LID D.T. 1994. Norsk Flora. Det Norske Samlaget, Oslo.

LINDBERG H. 1915. M. laxa Lehm. En misskänd art af Myosotis palustris-gruppen. Medd. Soc. Fauna Fl. Fenn. 41: 70-77.

LINDBERG H. 1934. Myosotis laxa Lehm. (M. baltica Samuelss.). Mem. Soc. Fauna Fl. Fenn. 1933-4, 10: 94-96.

Nikiforova O.D. 2001. Sistema roda Myosotis (Boraginaceae). Bot. Zhurn. 86 (12): 77-86. (in Russian)

NORDHAGEN R. 1940. Norsk Flora med kort omtale av innfrrrte treslag, pryd- og nytteplanter. Forlagt av H. Aschehoug, Co. (W. Nygaard), Oslo.

PALMGREN A. 1927. Die Einwanderungswege der Flora nach den Alandsinseln. Acta Bot. Fenn. 2: 1-198.

PLOOMPUU T. 1995. Harjumaa klindieelsete saarte soontaimed. In: Eesti LUS-i aastaraamat, vol. 76. TA Kirjastus, Tallinn, pp. 17-49.

PRZYVARA L. 1986/1987. Biosystematic studies on the series Palustres M. Pop. of the genus Myosotis L. from Poland. Fragm. Florist. Geobot. 31-32: 77-116.

REBASSOO H.-E. 1960. Hiiumaa laidude taimkattest. In: Eesti LUS-i aastaraamat, vol. 53. TA Kirjastus, Tallinn, pp. 95-112.

REBASSOO H.-E. 1997. Matsalu RLK saarte kõrgemate taimede floora nimestik. In: Loodusevaatlusi 95/96. Matsalu RLK, Tallinn, pp. 95-109.

REIER Ü. 1999. Perekond Lõosilm - Myosotis L. In: Leht M. (ed.), Eesti taimede määraja. Eesti Loodusfoto, Tartu, pp. 229-231.

SAIKI Y., OKEGAWA O. 1972. On Myosotis baltica Sam. found newly in Japan. Hokuriku-no-shokubutsu 20: 61-64. (in Japanese with English summary)

SAMUELSSON G. 1926. Myosotis baltica. In: Lindman C.A.M. Svensk fanerogamflora, ed. 2. Nordstedt, Stockholm, pp. 458.

SCHNEIDER S., ROESSLI D., EXCOFFIER L. 2000. ARLEQUIN ver. 2.000. A software for population genetics data analysis. Genetics and Biometry Laboratory, Switzerland.

SCHULTZ C.F. 1819. Prodromus Florae Stargardiensis. Suppl. 1. Sumtibus auctoris, Neubrandenburg.

SCHUSTER R. 1967. Taxonomische Untersuchungen über die Serie Palustres M. Pop. der Gattung Myosotis L. Feddes Repert. 74: 39-98.

StatSoft Inc. 2001. STATISTICA (data analysis software system), version 6. [www.statsoft.com].

STENBERG L., MOSSBERG B., ERICSSON S. 1992. Den nordiska floran. Wahlström, Widstrand, Turnhout. 
SWOFFORD D.L. 2002. PAUP: Phylogenetic Analysis Using Parsimony (and other methods). Version 4.0b10. Sinauer Associates, Sunderland, Massachusetts.

ULVINEN T. 1998. Boraginaceae - lemmikkikasvit. In: HämetAhti L., Suominen J., Ulvinen T., Uotila P. (eds.), Retkeilykasvio. Luonnontieteellinnen keskusmuseo, Kasvimuseo, Helsinki, pp. 352-354.

VILJASOO L. 1969. Perekond lõosilm e. meelislill - Myosotis L. In: Eichwald K., Eilart J., Kalda A., Kask M., Paivel A., Talts S., Viljasoo L. (eds), Eesti NSV Floora, vol. 4. Valgus, Tallinn, pp. 489-510.

VISSAK P. 1991. Matsalu Riikliku Looduskaitseala taimestik. Valgus, Tallinn.

WEIR B.S. 1996. Genetic data analysis II. Sinauer Associates Inc. Publishers, Sunderland Massachusetts.
WELLER S.G. 1985. Establishment of Lithospermum caroliniense on sand dunes: The role of nutlet mass. Ecology 65: 1893-1901.

WHITE T.J., BURNS T., LEE S., TAYLOR J. 1990. Amplification and direct sequencing of fungal ribosomal genes for phylogenetics. In: Innis M., Gelfand D., Sninsky J., White T. (eds), PCR Protocols: A Guide to Methods and Applications. Academic Press, New York, pp. 315-322.

WINKWORTH R.C., GRAU J., ROBERTSON A.W., LOCKHART P.J. 2002. The origins and evolution of the genus $M y-$ osotis L. (Boraginaceae). Molec. Phylog. Evol. 24: 180-193.

YUAN Y.M., SONG Y., GEUTEN K., RAHELIVOLOLONA E., WOHLHAUSER S., FISCHER E., SMETS E., KÜPFER P. 2004. Phylogeny and biogeography of Balsaminaceae inferred from ITS sequences. Taxon 53: 391-403. 